\title{
The Grand Challenges in the Quest for Peace and Democracy
}

\author{
Anastassia Obydenkova ${ }^{1,2,3+\star}$ and Thania Paffenholz $z^{4,5 t}$ \\ ${ }^{1}$ The Institute for Russian and Eurasian Studies, Uppsala University, Uppsala, Sweden, ${ }^{2}$ Center for Institutional Studies, Higher \\ School of Economics University, Moscow, Russia, ${ }^{3}$ The Institute for Economic Analysis of the Spanish Council for Scientific \\ Research, Barcelona, Spain, ${ }^{4}$ Graduate Institute of International and Development Studies, Geneva, Switzerland, ${ }^{5}$ Inclusive \\ Peace, Geneva, Switzerland
}

Keywords: peacebuilding, political regimes, conflict resolution, peace, autocracies, transition, democracy, democratization

\section{INTRODUCTION}

Peace and democracy are intertwined concepts. Immanuel Kant, writing in 1796, proposed that, if 'the consent of the citizens is required to decide whether or not war is to be declared, it is very natural that they will have great hesitation in embarking on so dangerous an enterprise'. Kant therefore suggested that a 'republican constitution' offers the potential to achieve 'a perpetual peace' (translation by Nisbet, 1991, 100). In more recent decades, the notion that 'democratic or liberal states never or very rarely go to war with each other' (Gat, 2006, 73) has been further developed and debated. Nevertheless, peace studies and democracy studies have tended to take different directions.

Academic research on the attainment of peaceful societies and democracy remains underdeveloped. Furthermore, the consequences and implications of achieving peace and democracy, and the wide variety of actors involved, lack conceptualization. The interactions between these processes and actors with the wide range of political regimes developed across the globe remain on the agenda of scholars and policymakers. This essay outlines a number of the key challenges facing peace and democracy studies as we enter the new decade of the 2020s. It aspires to advance our understanding of crucial empirical and theoretical questions and to establish a better dialogue between the fields of peace studies and democracy studies.

\section{PEACE STUDIES}

We see the need to address the following, among many, key challenges in the field of peace studies over the coming years:

The crisis of liberal peacebuilding: what comes next? The tenets of the 'liberal peace' dominated peacebuilding academia and practice in the 1990s, guiding peace process designs aimed at achieving multi-party democratic systems characterized by 'the rule of law, human rights, free and globalized markets and neo-liberal development' (Richmond, 2006, 292). However, the liberal peacebuilding project and its 'linear cause-effect problem-solving model' are now widely deemed to be in 'profound crisis' (Randazzo and Torrent, 2020, 3; De Coning, 2018, 302; Paffenholz, 2021) and the peace agreements struck in the heyday of liberal peacebuilding in the early 1990s have rarely produced lasting peace (Jarstad et al., 2015). Similarly, the democratization efforts of the 1990s proved a disappointment, frequently culminating in the consolidation of non-democratic regimes and autocracies, democratic backsliding and a rise in populism.

Academics have long recognized the more turbulent reality of peacemaking and peacebuilding (e.g. Paffenholz, 2021; Jarstad et al., 2019, 2; De Coning, 2018, 301; Bell and Pospisil, 2017, 583, 577; Rocha Menocal, 2017, 561, 567; Lederach, 2005, 118) while policymakers and donors, too, have embraced a more pragmatic, flexible and context-driven approach-at least in theory-termed the 'sustaining peace agenda' (e.g. UN, 2015a; UN, 2015b; EU, 2016; World Bank and UN, 2018). 
However, practitioners appear reluctant to abandon the linear, liberal peacebuilding model (Mahmoud et al., 2018; Autesserre, 2019; Ross, 2020; Paffenholz, 2021). While researchers have proposed 'local peacebuilding' as an alternative (Lederach, 2005; Mac Ginty and Richmond, 2013), this approach has also been criticized for essentializing and romanticizing the 'local' and neglecting power dynamics (Heathershaw, 2013; Paffenholz, 2015). There is a clear need for new peacebuilding paradigms that encourage and facilitate international and local peacebuilders to embrace a transformation in their practice.

Interrogating the 'inclusion project'. The notion that both peacemaking and peacebuilding must be inclusive can now be considered to be a predominant international norm (De Waal et al., 2017, 165; Turner, 2020). Numerous UN resolutions, frameworks and reports advocate the centrality of inclusion, from UNSCR Resolution 1325 (2000) to Resolution 2535 (2020). However, existing comparative research into the effects of inclusive peacemaking has faced criticism for its failure to establish a causal link between inclusion and sustainable peace (Pospisil, 2019, 99-100; De Waal et al., 2017, 180) and it has also been claimed that the notion of inclusion enables peacebuilding policy to uphold the appearance of agency' (Pospisil, 2019, 92) while merely make superficial changes to practice (Paffenholz et al., 2016; Paffenholz, 2021). This can be compared with the manner in which autocracies may include 'human rights' clauses in their constitutions in a bid to imitate democracies. ${ }^{1}$

More worrying, however, is a failure to distinguish between process and outcomes. It is not yet clear whether, and if so how, inclusive peacemaking and peacebuilding set communities on pathways toward more inclusive societies. As Rocha Menocal $(2017,560)$ has asked: 'where do more inclusive institutions come from in the first place? How and why do they emerge and evolve over time, and how can they be nurtured?' Castillejo $(2014,3)$ has also pointed out that, 'in many cases, excluded groups' participation in the peace process has not translated into significantly improved outcomes'. There is a clear need to interrogate whether the current inclusion modalities (Paffenholz, 2014) can truly pave the way toward more inclusive societies and, if not, what forms of peacemaking, peacebuilding and democracy promotion can do so.

Re-defining peace and finding new methods. Johan Galtung famously distinguished between negative peace, 'the absence of violence,' and positive peace, 'the integration of human society' (Galtung, 1964, 2). Notably, the integration of society, and accountability to this society, are key elements in the foundation of democracy. However, as Söderström et al. $(2020$, 1) have commented, while 'scholars have long recognized that peace is more than the absence of war... questions still remain as to how to appropriately define and study the phenomenon of peace'. Recent attempts have been

${ }^{1}$ The notions of inclusive approaches and sustainability are echoed in democracy studies, where discussion has focused on including, within academic research, all political regimes (as opposed to exclusively concentrating on democracies), and the sustainability of democratic regimes following transition (for instance, explorations of protecting young democracies from succumbing to populism). made to further our understanding of peace: the 'Everyday Peace Indicators' project (see Firchow and Mac Ginty, 2017), for instance, investigates alternative grassroots 'indicators' of peace. Furthermore, for Söderström et al. $(2020,2)$ the authors suggest that 'rather than asking where peace exists ... it is more fruitful to ask who is at peace or which relationships are most relevant to study in order to analyze peace'.

However, there is scope for further conceptual work in this vein and, concurrently, a need for additional consideration of the most appropriate methods-and combination of methods-for the study of peacemaking and peacebuilding, and for their overlap and engagement with democracy studies. Broadening our understanding of peace, together with our approach to the study of peace and democracy and the nexus between the two, must form goals as we move into the next decade.

\section{DEMOCRACY STUDIES}

Within democracy studies, there is a wide range of challenges to be addressed. For the sake of space, here we only focus on some of them: 1) encompassing all political regimes and processes; 2) the consequences and effects of political regimes; and 3) the nature of actors and their implications for political regimes.

Encompassing all political regimes. The first challenge is associated with accounting for all 'shades' of democracy, that is, for all existing political regimes. According to the latest available data in 2019, only one half of all states are democracies while the remainder are described as nondemocracies (ranging from consolidated autocracies to different shades of so-called hybrid political regimes). ${ }^{2}$ To address and solve global problems (such as climate change, wars and conflicts, global health crises and pandemics), it is important to account for all polities, including under-studied non-democratic regimes. Neglecting autocracies may critically aggravate these global issues. Our vision of the development of the study of democracies is to render the field more inclusive, encompassing the wide variety of existing political regimes and understanding their varied implications.

However, studying autocracies is more challenging due to their censorship, manipulated and controlled mass media, lack of transparency and disinformation, and mimicking of democratic practices and rhetoric. The 'mimicking trend' and combination of the decorative elements of democratic institutions with authoritarian practices have led scholars to re-define modern non-democracies as 'competitive autocracy' (Levitsky and Way, 2010), 'electoral autocracy' (Schelder, 2006), 'as a general term for all forms of non-democratic regimes' (Croissant and Wurster, 2013, 14), or as 'real existing autocracy' (Obydenkova and Schmitter, 2020). It is sufficient to say that the existing variety

${ }^{2}$ Different sources indicate approximately the same data on the total percentage of
democratic states with little variation, for example, Roser (2013). Freedom House is
more pessimistic: 'between 2005 and 2018, the share of Not Free countries rose to $26 \%$, while the share of Free countries declined to 44\%' (Freedom House, 2019). 
of political regimes should receive substantial attention in modern political science literature. To this end, our Section 'Peace and Democracy' aspires to focus on this variety of political regimes, addressing their implications for world politics and national developmental challenges.

Implications and effects of political regimes. The literature on the causes of democracy is relatively well-developed, embracing a wide range of theories of democratization such as natural resource curse, modernization, limiting factor theory, external influences, and historical legacies, to name a few (Beissinger and Kotkin, 2014; Libman and Obydenkova, 2014a, 2014b, 2021; Obydenkova and Libman, 2015b; Lankina T. V. et al, 2016; Whitehead, 1996; Teorell, 2010; Obydenkova and Libman, 2015a; Pop-Eleches and Tucker, 2017). In contrast, the studies on the implications, effects, and consequences of different political regimes for sub-national, national and international developments have received somewhat less academic attention.

Democracy, in general, is associated with better public policy, human rights, transparency, freedom of speech, and higher accountability of those in power (Diamond and Plattner, 2009). Despite this, there are still debates on the implications of democracy for public health, sustainable development, economic development, firm innovation, public trust, establishing peace and eradicating wars, and the environmental agenda among other issues (Ross, 2006; Andonova et. al 2007; Cao et. al. 2014; Ward et. al. 2014; Croissant and Wurster, 2013; Obydenkova and Salahodjaev, 2017; Obydenkova and Arpino, 2018; Arpino and Obydenkova, 2020; Nazarov and Obydenkova, 2020). These implications and consequences of democracy are still debated by scholars and across disciplines.

As to the effects of non-democratic regimes, there is some discussion on the internal implications (e.g. corruption, (de-) centralization and federalism, for local and sub-national political regimes, or national environmental issues and policies, see Andonova, 2003; Orttung, 2020; Obydenkova and Swenden, 2013; Hadenius and Teorell, 2007). However, a different set of nascent studies has focused on the external effects of nondemocracies for international cooperation, the emergence of new autocracy-led international organizations, wars and conflicts, global environmental challenges and climate change (e.g. Hadenius and Teorell, 2007; Levitsky and Way, 2010; Andonova et al., 2017; Pecency, 2001; Obydenkova and Libman, 2019). Disentangling this internal-external nexus of implications of all political regimes is a challenging task that must remain on the agenda for further studies of political regimes.

Actors in the studies of political regimes. In terms of 'actorness,' debates are advanced yet inconclusive. Traditionally, democratic nation-states have been the main actors in democracy promotion, however scholars have also recognized the prominent role played in recent years by international organizations (IOs) such as the EU and their impact on democratization, human rights, and advancing the environmental agenda among other issues (Andonova et al., 2007; Whitehead, 1996; Kopstein and Reilly, 2000; Börzel and Risse, 2012; Morlino, 2011; Lankina T. et al., 2016; Morlino and Quaranta, 2016; Obydenkova, 2008, 2012; Biermann, et al., 2009;
Biermann and Bauer, 2004; Börzel, 2003). Therefore, it is unsurprising that most of the existing studies have focused mainly on IOs established by democracies, such as the EU or the Western-led Multilateral Development Banks which emerged during the Cold War, and their nature, causes, and impacts (Pevehouse, 2002; Bartolini, 2005; Mansfield and Pevehouse, 2006; Börzel and Risse, 2012; Braaten, 2014; Ben-Artzi, 2016; Obydenkova and Vieira, 2020). However, recent decades have also witnessed a growing number of regional IOs which have been created by autocracies (Ambrosio, 2008; Libman and Obydenkova, 2013, 2018a, 2018b; Tansey, 2016; Allison, 2018; Izotov and Obydenkova, 2020; Kneuer and Demmelhuber, 2020). Interacting with many of these IOs which have been established and sponsored by non-democracies has become an important challenge for policy-makers in Europe and elsewhere around the globe. Notwithstanding the studies cited in this section, the multi-faceted influences of these IOs as actors remain to be addressed.

The impact of IOs, their mechanisms and channels of influence on political regimes of their member- and neighboring-states, as well as on sub-national regimes, have become one of the main recent challenges in studies of political regimes and their implications.

\section{CONCLUSION AND OVERARCHING CHALLENGES}

As the discussion above demonstrates, the international context in which peacemaking, peacebuilding, democratization, democracy and autocracy diffusion take place has shifted considerably in the first decades of the 21 st century. Global polarization, climate change, protracted conflicts, the COVID-19 pandemic, and the economic crises of 2008 and 2020 have coalesced to threaten stability, human rights, global health, sustainable development and security across the globe. Both peace and democracy studies must consider and find means of working within this fractured and turbulent international environment. This essay, due to the word limit, covers a fraction of the many challenges in sustaining peace and consolidating democracy faced by the world in the 21st century. As the editors of 'Peace and Democracy,' we aspire to open up the discussion of the multiple dimensions of political regimes, democracies, autocracies, peacemaking and peacebuilding from a multi-disciplinary perspective to contribute to the consolidation of democracy and inclusive peaceful societies around the world. Solving all existing academic debates is, of course, unrealistic; nonetheless, this Speciality Section hopes to become an open platform to present a variety of opinions, contradictions, and counter-intuitive findings on these and other issues related to the above-described agenda and beyond.

\section{AUTHOR CONTRIBUTIONS}

Authors are listed alphabetically and they contributed equally to this paper. 


\section{ACKNOWLEDGMENTS}

The authors are very grateful to the reviewer of this paper and to the support of Frontiers in Political Science provided for this project. The authors would also like to thank Sarah Clowry for her

\section{REFERENCES}

Allison, R. (2018). Protective Integration and Security Policy Coordination: Comparing the SCO and CSTO. J. Int. Polit. 11 (3), 297-338. doi:10.1093/cjip/poy008

Ambrosio, T. (2008). Catching the 'Shanghai Spirit': How the Shanghai Cooperation Organization Promotes Authoritarian Norms in Central Asia. Europe-Asia Stud. 60 (8), 1321-1344. doi:10.1080/09668130802292143

Andonova, L., Mansfield, E. D., and Milner, H. V. (2007). International Trade and Environmental Policy in the Postcommunist World. Comp. Polit. Stud. 40 (7), 782-807. doi:10.1177/0010414006293215

Andonova, L. B., Hale, T. N., and Roger, C. B. (2017). National Policy and Transnational Governance of Climate Change: Substitutes or Complements? Int. Stud. Q. 61 (2), 253-268. doi:10.1093/isq/sqx014

Andonova, L. B. (2003). Transnational Politics of the Environment: The European Union and Environmental Policy in Central and Eastern Europe. Cambridge, MA: MIT Press. doi:10.7551/mitpress/6908.001.0001

Arpino, B., and Obydenkova, A. V. (2020). Democracy and Political Trust before and after the Great Recession 2008: The European Union and the United Nations. Soc. Indic Res. 148 (2), 395-415. doi:10.1007/s11205-01902204-x

Autesserre, S. (2019). 'The Crisis of Peacekeeping: Why the UN Can't End Wars' Foreign Affairs [online]. Available at: https://www.foreignaffairs.com/articles/ 2018-12-11/crisis-peacekeeping (Accessed January 15, 2021).

Bartolini, S. (2005). Restructuring Europe: Centre Formation, System Building, and Political Structuring between the Nation State and the European Union. Oxford: Oxford University Press.

Beissinger, M., and Kotkin, S. (Editors) (2014). Historical Legacies of Communism in Russia and Eastern Europe. Cambridge, United Kingdom: Cambridge University Press.

Bell, C., and Pospisil, J. (2017). Navigating Inclusion in Transitions from Conflict: The Formalised PoliticalUnsettlement. J. Int. Dev. 29, 576-593. doi:10.1002/jid.3283

Ben-Artzi, R. (2016). Regional Development Banks in Comparison: Banking Strategies versus Development Goals. New York: Cambridge University Press. doi:10.1017/cbo9781316681398

Biermann, F., and Bauer, S. (2004). Assessing the Effectiveness of Intergovernmental Organisations in International Environmental Politics. Glob. Environ. Change. 14 (2), 189-193. doi:10.1016/S09593780(03)00025-6

Biermann, F., Siebenhuener, B., and Schreyögg, A. (2009). International Organizations in Global Environmental Governance (Abingdon: Routledge).

Börzel, T. A., and Risse, T. (2012). From Europeanisation to Diffusion: Introduction. West Eur. Polit. 35 (1), 1-19. doi:10.1080/01402382.2012.631310

Börzel, T. A. (2003). Environmental Leaders and Laggards in Europe. Aldershot: Ashgate. doi:10.1093/019925740x.001.0001

Braaten, D. B. (2014). Determinants of US Foreign Policy in Multilateral Development Banks. J. Peace Res. 51 (4), 515-527. doi:10.1177/0022343314524219

Cao, X., Milner, H. V., Prakash, A., and Ward, H. (2014). Research Frontiers in Comparative and International Environmental Politics: An Introduction. Comp. Political Stud. 47 (3), 291-308. doi:10.1177/0010414013509567

Castillejo, C. (2014). 'Promoting Inclusion in Political Settlements: a Priority for International Actors?' NOREF. Available at: https://www.dmeforpeace.org/wpcontent/uploads/2017/06/Promoting20Inclusion20in20Political20Settlements201. pdf (Accessed January 15, 2021)

Croissant, A., and Wurster, S. (2013). Performance and Persistence of Autocracies in Comparison: Introducing Issues and Perspectives. Contemp. Polit. 19 (1), 1-18. doi:10.1080/13569775.2013.773199

De Coning, C. (2018). Adaptive Peacebuilding. Int. Aff. 94 (2), 301-317. doi:10. 1093/ia/iix251 excellent research assistance. AO thanks the Center for Institutional Studies of the Higher School of Economics University (HSE University) for granting her the position of the leading research fellow. AO also acknowledges the support received from the Basic Research Program of the HSE University.

De Waal, A. (2017). "Inclusion in Peacemaking: from Moral Claim to Political Fact'," in The Fabric of Peace in Africa. Editors P. Aall and C. A. Crocker (Waterloo, Canada:: Centre for International Governance Innovation).

Diamond, L., and Plattner, M. F. (2009). Democracy: A Reader. (Baltimore: John Hopkins University Press).

EU (2016). 'Shared Vision, Common Action: a Stronger Europe: a Global Strategy for the European Union's Foreign and Security Policy'. Available at: http://eeas. europa.eu/archives/docs/top_stories/pdf/eugs_review_web.pdf (Accessed June $16,2020)$.

Firchow, P., and Ginty, R. M. (2017). Measuring Peace: Comparability, Commensurability, and Complementarity Using Bottom-Up Indicators. Int. Stud. Rev. 19 (1), 6-27. doi:10.1093/isr/vix001

Freedom House (2019). Freedom in the World 2019: Democracy in Retreat. Available at: https://freedomhouse.org/report/freedom-world/2019/democracy-retreat (Accessed April 18, 2021)

Galtung, J. (1964). A Structural Theory of Aggression. J. Peace Res. 1 (2), 95-119. doi:10.1177/002234336400100203

Gat, A. (2006). 'The Democratic Peace Theory Reframed: the Impact of Modernity'. World Polit. 58, 73-100. doi:10.1353/wp.2006.0017

Hadenius, A., and Teorell, J. (2007). Pathways from Authoritarianism. J. Democracy 18 (1), 143-157. doi:10.1353/jod.2007.0009

Heathershaw, J. (2013). Towards Better Theories of Peacebuilding: beyond the Liberal Peace Debate. Peacebuilding 1 (2), 275-282. doi:10.1080/21647259. 2013.783260

Izotov, V., and Obydenkova, A. (2020). Geopolitical Games in Eurasian Regionalism: Ideational Interactions and Regional International Organisations. Post-Commun. Econ. 14, 33. doi:10.1080/14631377.2020.1793584

Jarstad, A., Olivius, E., Åkebo, M., Höglund, K., Kovacs, M. S., Söderström, J., et al. (2015). 'Peace Agreements in the 1990s-what Are the Outcomes 20 Years Later?' Umeå Working Papers in Peace and Conflict Studies 8. Available at https://www.diva-portal.org/smash/get/diva2:887947/FULLTEXT02 (Accessed January 15, 2021).

Jarstad, A., Eklund, N., Johansson, P., Olivius, E., Saati, A., Sahovic, D., et al. (2019). Three Approaches to Peace: a Framework for Describing and Exploring Varieties of Peace' Umeå Working Papers in Peace and Conflict Studies 12. Available at: https:/ceb01de1-7982-420a-bab3-2061a5652816.filesusr.com/ ugd/22642a_1d89ad936d9c40d38754232e11a7a481.pdf (Accessed January 15, 2021)

Kneuer, M., and Demmelhuber, T. (2020). Authoritarian Gravity Centers A CrossRegional Study of Authoritarian Promotion and Diffusion. London and New York: Routledge. doi:10.4324/9781003008804

Kopstein, J. S., and Reilly, D. A. (2000). Geographic Diffusion and the Transformation of the Postcommunist World. World Pol. 53 (1), 1-37. doi:10.1017/s0043887100009369

Lankina, T. V., Libman, A., and Obydenkova, A. (2016a). Appropriation and Subversion. World Pol. 68 (2), 229-274. doi:10.1017/s0043887115000428

Lankina, T., Libman, A., and Obydenkova, A. (2016b). Authoritarian and Democratic Diffusion in Post-Communist Regions. Comp. Polit. Stud. 49 (12), 1599-1629. doi:10.1177/0010414016628270

Lederach, J. P. (2005). The Moral Imagination: The Art and Soul of Building Peace. Oxford, MA: Oxford University Press. doi:10.1093/0195174542.001.0001

Levitsky, S., and Way, L. (2010). Competitive Authoritarianism: Hybrid Regimes after the Cold War. Chennai, TN: Cambridge University Press. doi:10.1017/ cbo9780511781353

Libman, A., and Obydenkova, A. (2013). Informal Governance and Participation in Non-democratic International Organizations. Rev. Int. Organ. 8 (2), 221-243. doi:10.1007/s11558-012-9160-y

Libman, A., and Obydenkova, A. (2014a). International Trade as a Limiting Factor in Democratization: an Analysis of Subnational Regions in Post- 
Communist Russia. St Comp. Int. Dev. 49 (2), 168-196. doi:10.1007/s12116013-9130-2

Libman, A., and Obydenkova, A. (2014b). Governance of Commons in a Large Nondemocratic Country: The Case of Forestry in the Russian Federation. Publius: J. Federalism. 44 (2), 298-323. doi:10.1093/publius/pjt065

Libman, A., and Obydenkova, A. V. (2018a). Understanding Authoritarian Regionalism. J. Democracy. 29 (4), 151-165. doi:10.1353/jod.2018.0070

Libman, A., and Obydenkova, A. V. (2018b). Regional International Organizations as a Strategy of Autocracy: The Eurasian Economic Union and Russian Foreign Policy. Int. Aff. 94 (5), 1037-1058. doi:10. 1093/ia/iiy147

Libman, A., and Obydenkova, A. (2021). Historical Legacies of Communism: Modern Politics, Society, and Economic Development. Cambridge, NY: Cambridge University Press. doi:10.1017/9781108900133

Mac Ginty, R., and Richmond, O. P. (2013). The Local Turn in Peace Building: a Critical Agenda for Peace. Third World Q. 34 (5), 763-783. doi:10.1080/ 01436597.2013.800750

Mahmoud, Y., Connolly, L., and Mechoulan, D. (2018). 'Sustaining Peace in Practice: Building on what Works' International Peace Institute. Available at: https://www.ipinst.org/wp-content/uploads/2018/02/1802_Sustaining-Peacein-Practice.pdf (Accessed: 16 June 2020).

Mansfield, E. D., and Pevehouse, J. C. (2006). 'Democratization and International Organizations'. Int. Organ. 60, 137-167. doi:10.1017/ s002081830606005x

Morlino, L., and Quaranta, M. (2016). What Is the Impact of Economic Crisis on Democracy? Evid. Europe' Int. Polit. Sci. Rev. 37 (5), 1-16. doi:10.1177/ 0192512116639747

Morlino, L. (2011). Changes for Democracy. Actors, Structures, Processes. Oxford Studies: Oxford University Press. doi:10.1093/acprof:oso/9780199572533.001. 0001

Nazarov, Z., and Obydenkova, A. V. (2020). Democratization and Firm Innovation: Evidence from European and Central Asian Post-communist States. PostCommun. Econ. 32 (7), 833-859. doi:10.1080/14631377.2020.1745565

Nisbet, H. B. (1991). Kant: Political Writings. Editor H. Reiss (Cambridge: Cambridge University Press).

Obydenkova, A. V., and Arpino, B. (2018). Corruption and Trust in the European Union and National Institutions: Changes over the Great Recession across European States. JCMS: J. Common Market Stud. 56 (3), 594-611. doi:10.1111/ jcms. 12646

Obydenkova, A., and Libman, A. (2015a). Causes and Consequences of Democratization: The Regions of Russia. London-New York: Routledge Publishing. doi:10.4324/9781315745428

Obydenkova, A. V., and Libman, A. (2015b). Autocratic and Democratic External Influences In Post-Soviet Eurasia. Surrey and Burlington: Ashgate.

Obydenkova, A. V., and Libman, A. (2019). Authoritarian Regionalism In the World Of International Organizations: Global Perspective And Eurasian Enigma. Oxford and New York: Oxford University Press.

Obydenkova, A., and Salahodjaev, R. (2017). Climate Change Policies: The Role of Democracy and Social Cognitive Capital. Environ. Res. 157, 182-189. doi:10. 1016/j.envres.2017.05.009

Obydenkova, A., and Schmitter, P. (2020). "Real Existing Democracies' and 'Real Existing Autocracies': Their Relation to Regional Integration and Regional Cooperation Taiwan. J. Democracy 16 (1), 1-25. doi:10.1111/1468-2427. 12179

Obydenkova, A., and Swenden, W. (2013). Autocracy-Sustaining versus Democratic Federalism: Explaining the Divergent Trajectories of Territorial Politics in Russia and Western Europe. Territory, Polit. Governance. 1 (1), 86-112. doi:10.1080/21622671.2013.763733

Obydenkova, A. V., and Vieira, V. G. R. (2020). The Limits of Collective Financial Statecraft: Regional Development Banks and Voting Alignment with the United States at the United Nations General Assembly. Int. Stud. Q. 64 (1), 13-25. doi:10.1093/isq/sqz080

Obydenkova, A. (2008). Regime Transition in the Regions of Russia: The Freedom of Mass Media: Transnational Impact on Sub-national Democratization? Eur. J. Polit. Res. 47 (2), 221-246. doi:10.1111/j.14756765.2007.00727.x
Obydenkova, A. V. (2012). Democratization at the Grassroots: the European Union's External Impact. Democratization 19 (2), 230-257. doi:10.1080/ 13510347.2011.576851

Orttung, R. W. (2020). Urban Sustainability in the Arctic: Measuring Progress in Circumpolar Cities. New York City: Berghahn Books.

Paffenholz, T., Ross, N., Dixon, S., Shluchter, A. L., and True, J. (2016). Making Women Count - Not Just Counting Women: Assessing Women's Inclusion and Influence on Peace Negotiations' IPTI. Available at: https://www.alnap.org/ system/files/content/resource/files/main/ipti-un-women-report-making-womencount-60-pages.pdf (Accessed: January 18, 2021).

Paffenholz, T. (2014). Civil Society and Peace Negotiations: beyond the Inclusion-Exclusion Dichotomy. Negotiation J. 30 (1), 69-91. doi:10.1111/ nejo.12046

Paffenholz, T. (2015). Unpacking the Local Turn in Peacebuilding: a Critical Assessment towards an Agenda for Future Research. Third World Q. 36 (5), 857-874. doi:10.1080/01436597.2015.1029908

Paffenholz, T. (2021). 'Perpetual Peacebuilding: a New Paradigm to Move beyond the Linearity of Liberal Peacebuilding'. J. Intervent. Statebuild.. doi:10.1080/ 17502977.2021.1925423

Pevehouse, J. C. (2002). With a Little Help from My Friends? Regional Organizations and the Consolidation of Democracy. Am. J. Polit. Sci. 46 (3), 611-626. doi:10.2307/3088403

Pop-Eleches, G, and Tucker, J. A. (2017). Communism's Shadow: Historical Legacies and Contemporary Political Attitudes. Princeton, NJ: Princeton University Press.

Pospisil, J. (2019). Peace in Political Unsettlement: Beyond Solving Conflict. London, UK: Palgrave MacMillan. doi:10.1007/978-3-030-04318-6

Randazzo, E., and Torrent, I. (2020). Reframing Agency in Complexity-Sensitive Peacebuilding. Security Dialogue 52, 096701062090430. doi:10.1177/ 0967010620904306

Richmond, O. P. (2006). The Problem of Peace: Understanding the 'liberal Peace'. Conflict, Security Development 6 (3), 291-314. doi:10.1080/ 14678800600933480

Rocha Menocal, A. (2017). Political Settlements and the Politics of Transformation: Where Do 'Inclusive Institutions' Come from? J. Int. Dev. 29, 559-575. doi:10. $1002 /$ jid. 3284

Roser, Max. (2013). "Democracy”. Published Online at OurWorldInData.Org. Available at: https://ourworldindata.org/democracy (Accessed April 18, 2021).

Ross, M. (2006). Is Democracy Good for the Poor? Am. J. Polit. Sci. 50 (4), 860-874. doi:10.1111/j.1540-5907.2006.00220.x

Ross, N. (2020). 'Donor Support to Peace Processes: a Lessons for Peace Literature Review' ODI. Available at: https://www.odi.org/sites/odi.org.uk/files/resourcedocuments/lessons_for_peace_lit_review_i.pdf (Accessed June 16, 2020).

Schelder, A. (2006). Electoral Authoritarianism: The Dynamics Of Unfree Competition. Boulder, CO: Lynne Rienner).

Söderström, J., Åkebo, M., and Jarstad, A. K. (2020). Friends, Fellows, and Foes: A New Framework for Studying Relational Peace. Int. Stud. Rev. 17, 29. doi:10. 1093/isr/viaa033

Tansey, O. (2016). International Politics of Authoritarian Rule. London and New York: Oxford University Press. doi:10.1093/acprof:oso/9780199683628.001. 0001

Teorell, J. (2010). Determinants of Democratization: Explaining Regime Change in the World, 1972-2006. Cambridge UK: Cambridge University Press. doi:10.1017/cbo9780511762727

Turner, C. (2020). "Mapping a Norm of Inclusion in the Jus Post Bellum," in The Justice of Peace and Jus Post Bellum. Editors C. Stahn, J. Iverson, and J. Easterday (Chennai, TN: Oxford University Press).

UN (2015a). 'The Challenge of Sustaining Peace: Report of the Advisory Group of Experts for the 2015 Review of the United Nations Peacebuilding Architecture'. Available at: https://reliefweb.int/report/world/challenge-sustaining-peacereport-advisory-group-experts-2015-review-united-nations (Accessed January $15,2021)$.

UN (2015b). 'Uniting Our Strengths for Peace-Politics, Partnership and People: Report of the High-Level Independent Panel on United Nations Peace Operations'. Available at: http://providingforpeacekeeping.org/project/ 
uniting-our-strengths-for-peace-politics-partnerships-and-people-report-ofthe-high-level-independent-panel-on-united-nations-peace-operations-2015/ (Accessed June 16, 2020)

Ward, H., Cao, X., and Mukherjee, B. (2014). State Capacity and the Environmental Investment Gap in Authoritarian States. Comp. Political Stud. 47 (3), 309-343. doi:10.1177/0010414013509569

Whitehead, L. (1996). International Dimension of Democratization: Europe and the Americas. (Oxford: Oxford University Press).

World Bank and UN (2018). 'Pathways for Peace: Inclusive Approaches to Preventing Violent Conflict'. Available at: https://openknowledge. worldbank.org/handle/10986/28337 (Accessed June 16, 2020).
Conflict of Interest: The authors declare that the research was conducted in the absence of any commercial or financial relationships that could be construed as a potential conflict of interest.

Copyright (c) 2021 Obydenkova and Paffenholz. This is an open-access article distributed under the terms of the Creative Commons Attribution License (CC $B Y)$. The use, distribution or reproduction in other forums is permitted, provided the original author(s) and the copyright owner(s) are credited and that the original publication in this journal is cited, in accordance with accepted academic practice. No use, distribution or reproduction is permitted which does not comply with these terms. 